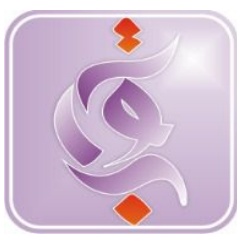

\title{
STRES KERJA DENGAN KEHARMONISAN KELUARGA PADA KARYAWAN
}

Received: 27th December 2017; Revised: $10^{\text {th }}$ January 2018; Accepted: $28^{\text {th }}$ February 2018

\section{Subhan Ajrin Sudirman}

UIN Imam Bonjol Padang

Email: Subhanajrin@uinib.ac.id

\begin{abstract}
Abstrak : Organisasi yang baik tercipta oleh tenaga kerja atau sumber daya manusia (SDM). Perlu berbagai usaha yang dilakukan organisasi agar tujuan yang telah ditetapkan dapat dicapai secara maksimal. Manusia merupakan faktor yang sangat penting karena berhasil atau tidaknya suatu usaha sebagian besar ditentukan oleh karyawan. Sehingga sumber daya manusia (SDM) merupakan aset utama yang sangat besar pengaruhnya terhadap kemajuan perusahaan. Berbagai bentuk pekerjaan yang dilakukan dapat menyebabkan timbulnya masalah. Masalah yang muncul baik internal dan eksternal. Masalah internal seperti kesehatan yang tidak baik, kurangnya istirahat, maupun emosi yang tidak terkontrol. Sedangkan masalah eksternal seperti pekerjaan yang menumpuk, adanya tekanan di tempat kerja, kurangnya rasa nyaman di tempat bekerja, karena hal ini akan mempengaruhi cara kerja karyawan dalam bekerja. Stres kerja menurut para ahli dapat menimbulkan dampak keharmonisan keluarga. Hal ini karena pekerja yang stres akan mempengaruhi kehidupan pribadi dan keluarganya. Tulisan ini akan menguraikan stres kerja pada karyawan serta bagaimana stres kerja itu mempengearuhi keharmonisan keluarga.
\end{abstract}

Kata Kunci : Stres kerja, keharmonisan keluarga, karyawan.

\section{LATAR BELAKANG}

Berbagai usaha dilakukan organisasi agar tujuan yang telah ditetapkan dapat dicapai secara maksimal. Manusia merupakan faktor yang sangat penting karena berhasil atau tidaknya suatu usaha sebagian besar ditentukan oleh karyawan. Sehingga sumber daya manusia (SDM) merupakan aset utama yang sangat besar pengaruhnya terhadap kemajuan perusahaan.

Pekerjaan yang dilakukan dapat menyebabkan timbulnya masalah. Masalah yang muncul baik internal dan eksternal. Masalah internal seperti kesehatan yang tidak baik, kurangnya istirahat, maupun emosi yang tidak terkontrol. Sedangkan masalah eksternal seperti pekerjaan yang menumpuk, adanya tekanan di tempat kerja, kurangnya rasa nyaman di tempat bekerja, karena hal ini akan mempengaruhi cara kerja karyawan dalam bekerja.

Stres merupakan salah satu bentuk tekanan di tempat kerja. Menurut Anoraga (2014:108), secara sederhana stres merupakan suatu bentuk tanggapan seseorang baik secara fisik maupun mental terhadap suatu perubahan di lingkungannya yang dirasakan mengganggu dan mengakibatkan dirinya terancam.

Akibat karyawan yang mengalami stres di lingkungan kerjanya dapat memengaruhi kemampuan karyawan tersebut dalam bekerja. Salah satu alasan mengapa stres perlu untuk dibahas adalah orang yang stres tidak dapat bekerja secara optimal 
sehingga akan memberi dampak negatif pada hasil kerjanya dan juga dalam lingkungan sosialnya.

Seiring berjalannya waktu, pekerjaan tidak hanya didominasi oleh laki-laki, namun juga banyak digeluti oleh perempuan. Menurut Ali dalam Mahmudah (2009:213), perempuan dianggap lebih rendah dari lakilaki, tidak cocok menduduki suatu kekuasaan ataupun memiliki kemampuan yang setara dengan laki-laki. Semakin besar jumlah wanita yang bekerja dan semakin banyak wanita yang berhasil memasuki jenis-jenis pekerjaan yang selama ini belum pernah dimasuki kaum hawa.

Wanita dalam meniti karir mempunyai beban lebih dibanding rekan prianya, wanita terlebih dulu harus mengatasi urusan keluarga dan hal-hal yang menyangkut rumah tangga, kedua peran ini dijalani dalam waktu bersamaan. Dampak dari peran ganda adalah berkurangnya waktu dan perhatian terhadap suami dan anak-anak, ibu yang bekerja di luar rumah dianggap kurang berperan secara emosional dan kurang menyediakan waktu dalam pengasuhan anak. Masalah lainnya yang muncul adalah pengaturan waktu, stres dan kelelahan. Martaniah (dalam Hartati, 2000:2).

Peran sebagai ibu rumah tangga tetap harus dilakukan oleh wanita yang bekerja, hal ini dapat berdampak terhadap kelangsungan hidup keluarga yang harmonis dan tentram, menjaga keselarasan dan keserasian dalam kehidupan berumah tangga. Dalam menciptakan keharmonisan dalam keluarga, wanita yang bekerja akan berusaha menciptakan keseimbangan antara pekerjaan dengan urusan rumah tangga.

\section{PEMBAHASAN}

\section{A. Stres Kerja \\ Pengertian Stres Kerja}

Dalam membicarakan stres kerja perlu terlebih dahulu mengerti pengertian stres secara umum. Menurut Chaplin (2005:488) stres merupakan keadaan tertekan, baik secara fisik maupun psikologis, istilah stres adalah tanggapan maupun proses internal atau eksternal yang mencapai tingkat ketegangan fisik dan psikologis sampai pada batas kemampuan subjek.

Stres secara sederhana didefinisikan sebagai memburuknya keadaan emosi dan fisik dalam hidup, stres bisa dianggap sebagai respon tubuh terhadap hidup ini sendiri. Dalam kehidupan modern yang makin kompleks, manusia akan cenderung mengalami stres apabila ia kurang mampu mengadaptasikan keinginan dengan kenyataan, baik kenyataan yang ada di dalam maupun di luar dirinya, secara sederhana stres merupakan suatu bentuk tanggapan seseorang, baik secara fisik maupun mental, terhadap suatu perubahan di lingkungannya yang dirasakan mengganggu dan mengakibatkan dirinya terancam (Anoraga, 2014:108).

Harrisma dalam Gibson (2011:339) mendefinisikan stres kerja suatu tanggapan penyesuaian, diperantarai oleh perbedaan individu atau proses psikologis, akibat dari setiap tindakan lingkaran situasi atau peristiwa yang menetapkan permintaan psikologi atau fisik berlebihan kepada seseorang.

Stres merupakan situasi yang mungkin dialami manusia pada umumnya dan pegawai pada khususnya dalam organisasi atau perusahaan. Stres menjadi masalah penting karena situasi itu dapat mempengaruhi kepuasan kerja dan produktivitas kerja, perasaan tertekan yang dialami karyawan dalam menghadapi pekerjaan, ini tampak dari simptom antara lain emosi, menyendiri, sulit tidur, merokok yang berlebihan, tidak bisa rileks, cemas, tegang, gugup, tekanan darah meningkat, 
dan mengalami gangguan pencernaan, Harrisma dalam Mangkunegara (2008:157).

Istilah stres menunjukkan adanya tekanan atau kekuatan pada tubuh, dalam psikologi kita menggunakan istilah stres menunjukkan suatu tekanan atau tuntutan yang dialami individu agar ia beradaptasi atau menyesuaikan diri, sumber stres disebut stressor (Munandar, 2001:374). Stressor menyangkut faktor-faktor psikologis seperti hubungan sosial, perubahan hidup seperti kematian orang tercinta, perceraian, atau pemutusan hubungan kerja (PHK), dan juga menyangkut masalah sehari-hari seperti kemacetan lalu lintas dan faktor lingkungan fisik seperti kebisingan dan suhu udara yang terlalu panas dan dingin.

Stres sebagai suatu keadaan yang dapat mempengaruhi kondisi fisik dan mental seseorang pada saat dia dihadapkan pada sebuah kesempatan, keterbatasan atau tuntutan yang dihubungkan dengan apa yang diinginkannya yang hasilnya kemudian dipersepsikan sebagai sesuatu yang tidak pasti. Stres tidak selalu memilki dampak negatif, stres juga memilki dampak positif, terutama bila stres tersebut dapat memberikan suatu input yang memilki potensi, seperti pada motivasi pribadi, rangsangan untuk bekerja lebih keras, dan meningkatnya inspirasi hidup yang lebih baik Dhania dalam Baron (2000:206).

Dapat disimpulkan bahwa stres kerja merupakan suatu keadaan yang timbul dalam interaksi di antara manusia dengan pekerjaan sehingga mempengaruhi kepuasan kerja dan produktivitas kerja tidak mampu untuk menghadapi berbagai tuntutan terhadap dirinya secara efektif respon non spesifik dari tubuh terhadap permintaan yang dibuat untuk itu.

Kondisi-kondisi yang menyebabkan stres disebut stressor, stres dapat disebabkan oleh beban pekerjaan yang semakin besar, hal ini berdampak pada gejala fisik seperti kelelahan dan gejala afektif seperti perasaan yang terganggu. Menurut Dhania dalam Baron dan Grenberg (2000:228), penyebab stres yang bertalian dengan kondisi kerja adalah tuntutan pekerjaan, konflik peran, peran ganda, beban pekerjaan, tanggung jawab terhadap orang lain, kurangnya dukungan sosial dan partisipasi dalam mengambil keputusan

\section{Gejala-Gejala Stres}

Stres adalah kondisi yang memicu stres pada orang lain. Ananta \& Ellitan (2009:71) menerangkan, stres yang dialami individu dalam lingkungan kerjanya sering kali dipicu oleh hal-hal yang berasal dari dalam individu (internal) dan dari luar (eksternal) yang membawa konsekuensi berbeda bagi masing-masing individu tergantung bagaimana mereka merespon penyebab stres.

Stres mempengaruhi baik pada fisik maupun proses mental dan nantinya, keduanya akan mempengaruhi bagaimana berperilaku di bawah tekanan yang berat, dan mempengaruhi tingkatan di mana bisa melanjutkan peran di rumah dan di tempat kerja secara efektif dan efisien. Dhania dalam Baron (2000:230) menjelaskan bahwa kondisi stres didiagnosa berdasarkan 3 jenis gejala yaitu gejala fisik, perilaku, dan tempat kerja, dimana gejala-gejala tersebut dapat membuat waspada terhadap kenyataan bahwa kita berada di bawah pengaruh stres.

1. Gejala Fisik

Nafas menjadi semakin cepat, mulut dan kerongkongan kering, kedua tangan menjadi basah oleh keringat, tubuh merasa gerah, otot-otot menjadi tegang, tubuh mengalami gangguan pencernaan, diare, sembelit, badan terasa lelah, kepala menjadi sakit dan tegang, berkedut (kejang-kejang atau bergetarnya urat-urat pada kelopak mata, kadang dianggap sebagai pertanda atau firasat akan terjadinya sesuatu, dan perasaan sangat gelisah). Tentu saja, gejala seperti ini dapat dialami dalam kehidupan normal sebagai akibat gerak fisik yang biasa. Semua itu menjadi gejala stres apabila tidak ada penyebabnya dan beberapa diantaranya muncul pada saat yang sama atau saat kita mengalaminya lebih sering daripada yang kita harapkan.

\section{Gejala Perilaku}


a. Perasaan terganggu, khawatir, sedih, salah paham, tidak berdaya, tidak mampu mengatasi persoalan yang dihadapi, gelisah, merasa gagal, tidak termotivasi untuk bekerja.

b. Kesulitan berkosentrasi, berpikir jernih, membuat keputusan.

c. Hilangnya kreativitas bekerja, minat terhadap orang lain.

Mengenali cara seperti itu, baik yang ada dalam diri sendiri maupun di dalam diri orang lain, tanpa menyadari bagaimana stres mempengaruhi kita. Merasa kecewa, marah dan canggung, atau sebentar-sebentar terbangun di malam hari karena memikirkan pekerjaan. Mendapatkan kesulitan untuk berkonsentrasi, untuk berpikir secara jernih, atau untuk mengambil keputusan, atau mengalami kehilangan kreativitas dan semakin kurang perhatian terhadap diri sendiri maupun terhadap orang lain.

\section{Gejala di tempat kerja}

Kita menghabiskan waktu dari sebagian besar hidup kita ketika berada di tempat kerja. Apabila terkena stres, gejala-gejala itu dapat mempengaruhi kita di tempat kerja dan sering kali melalui cara sebagai berikut: menurunnya kepuasan kerja, menurunnya kinerja, hilangnya semangat dan energi, komunikasi yang tidak lancar, buruknya pengambilan keputusan, berkurangnya kreativitas dan inovasi, dan terfokusnya perhatian ke tugas-tugas yang justru tidak produktif.

Dengan mengenali dan mengakui semua perubahan ini, kita dapat mencegah sekurang-kurangnya sebagian dari akibatakibat stres dalam jangka waktu yang lebih lama dalam berperilaku di tempat kerja, akibat ini dapat dilihat melalui kesehatan, prestasi dan produktivitas seseorang.

\section{KEHARMONISAN KELUARGA PENGERTIAN KEHARMONISAN KELUARGA}

Keharmonisan rumah tangga proses dinamis yang melibatkan kepiawaian seluruh anggota keluarga dan dialog adalah keniscayaan dalam setiap prosesnya (Ronosulistyo, Rosalina dan Angelina, 2009). Keharmonisan keluarga adalah bagaimana suami dan istri dapat melakukan komunikasi, motivasi, serta mengetahui lebih dalam tentang pasangannya dalam mengembangkan hubungannya sebagai suatu keluarga. Keharmonisan keluarga ukuran dari persepsi standar dari pola perilaku keluarga yang mencerminkan sinkronisasi dan integrasi di antara anggota keluarga yang juga diindikasikan melalui anggota keluarga.

Keluarga merupakan tempat penghuninya istirahat dari suatu kepenatan aktivitas sehingga keluarga haruslah menyenangkan, menurut Tirtawinata dalam Friedman (2010:09), keluarga didefinisikan sebagai sistem sosial kecil yang terbuka yang terdiri atas suatu rangkaian bagian yang sangat saling bergantung dan dipengaruhi oleh struktur maupun lingkungan eksternal, keluarga yang harmonis erat kaitannya dengan kondisi keluarga yang tenang tidak ada gejolak, tenteram, bahagia, dan damai.

Menikah tidak sulit tetapi membangun keluarga bahagia bukan sesuatu yang mudah, pekerjaan membangun pertama harus didahului dengan adanya gambar yang merupakan konsep dari bangunan yang diinginkan. Orang yang ingin membangun keluarga bahagia terlebih dahulu harus memiliki konsep tentang keluarga bahagia itu sendiri (Mubarok, 2009).

Keharmonisan keluarga adalah keadaan selaras atau serasi serta bertujuan untuk mencapai keselarasan dan keserasian dalam kehidupan rumah tangga perlu menjaga kedua hal tersebut untuk menjaga keharmonisan, menurut Kamus Besar Bahasa Indonesia (KBBI, 2012) keharmonisan keluarga adalah keadaan yang selaras atau serasi.

Menurut Gunarsah (2004:209)

keharmonisan keluarga seluruh anggota keluarga merasa bahagia yang ditandai oleh 
berkurangnya ketegangan, kekecewaan dan puas terhadap seluruh keadaan dan keberadaan dirinya (eksistensi dan aktualisasi diri) yang meliputi aspek fisik emosional dan sosial. Konsep keluarga bahagia yang islami biasanya disebut dengan istilah keluarga sakinah menurut Mubarok (2009: 143\&148), keluarga sakinah kondisi yang sangat ideal dalam kehidupan, keluarga yang ideal biasanya jarang terjadi, oleh karena itu dia tidak terjadi secara mendadak tetapi ditopang oleh pilar-pilar yang kokoh, yang memerlukan perjuangan dan butuh waktu serta pengorbanan terlebih dahulu.

Hubungan yang menciptakan ketentraman hati, ketenangan pikiran, kebahagiaan jiwa, dan kesenangan jasmaniah, serta dapat mengantarkan seseorang hidup lebih bahagia, lebih layak dan lebih tentram, menurut Sadarjoen (2005:68) keharmonisan dalam keluarga antara lain sebagai berikut:

\section{Keimanan keluarga.}

Keimanan merupakan penentu penting, yaitu penentu tentang keyakinan atau agama yang akan di pilih oleh kedua pasangan.

\section{Continuous improvement.}

Terkait dengan sejauh mana tingkat kepekaan perasaan antar pasangan kepekaan perasaan antar pasangan terhadap tantangan permasalahan pernikahan.

3. Kesepakatan tentang perencanaan jumlah anak.

Sepakat untuk menentukan berapa jumlah anak yang akan dimiliki suatu pasangan yang baru menikah.

4. Kadar rasa bakti pasangan terhadap orang tua dan mertua

Keadilan dalam memperlakukan kedua belah pihak keluarga, orang tua dan mertua beserta keluarga besarnya.

Menurut Gunarsa (2012:16), terdapat beberapa penyebab yang mempengaruhi keharmonisan keluarga yaitu suasana rumah yang harus diciptakan sedemikian rupa sehingga menjamin timbulnya suasana dan perasaan aman. Hal ini bukan berarti bahwa di dalam keluarga tersebut tidak ada masalah yang harus diatasi atau perselisihan paham yang tercetus dalam pertengkaran, hal yang juga mempengaruhi keharmonisan keluarga menurut Gunarsa (2000), adalah kondisi ekonomi keluarga tingkat sosial ekonomi yang rendah sering menjadi penyebab terjadinya permasalahan dalam sebuah keluarga. Akibat banyaknya masalah yang ditemui karena kondisi keuangan yang memprihatinkan ini menyebabkan kondisi keluarga menjadi tidak harmonis.

\section{KRITERIA}

\section{KELUARGA}

KEHARMONISAN

Keharmonisan keluarga berkaitan erat dengan suasana hubungan perkawinan yang bahagia dan serasi serta harmonis. Stinnet dan Defrain (dalam Hawari, 1996: 208-209), mengemukakan bahwa sebagai suatu pegangan menuju perkawinan atau keluarga yang harmonis adalah:

1. Menciptakan kehidupan yang beragama

Sebuah keluarga yang harmonis ditandai dengan terciptanya kehidupan beragama dalam rumah tersebut, hal ini penting karena dalam agama terdapat nilai-nilai moral dan etika kehidupan. Berdasarkan beberapa penelitian ditemukan bahwa keluarga yang tidak religius yang penanaman komitmennya rendah atau tidak ada nilai agama sama sekali cenderung terjadi pertentangan konflik dalam keluarga, dengan suasana yang seperti ini maka anak akan merasa tidak betah berada di rumah dan kemungkinan besar anak akan mencari lingkungan lain yang dapat menerimanya.

2. Mempunyai waktu bersama

Keluarga yang harmonis selalu menyediakan waktu untuk bersama keluarganya, baik itu hanya sekedar berkumpul, makan bersama, dan menemani anak bermain, dalam kebersaman ini anak akan merasa dirinya dibutuhkan dan diperhatikan oleh orangtuanya sehingga anak akan betah tinggal di rumah.

3. Mempunyai komunikasi yang baik antar anggota keluarga

Komunikasi merupakan dasar untuk terciptanya keharmonisan dalam keluarga, remaja akan merasa aman apabila 
orangtuanya tampak rukun karena kerukunan tersebut akan memberikan rasa aman dan ketenangan bagi anak, komunikasi yang baik dalam keluarga juga akan dapat membantu remaja untuk memecahkan permasalahan yang dihadapinya di luar rumah. Selain berperan sebagai orangtua, ibu dan ayah juga berperan sebagai teman, agar anak lebih leluasa dan terbuka dalam menyampaikan semua permasalahannya.

\section{Saling menghargai antar sesama anggota keluarga}

Keluarga yang harmonis adalah keluarga yang memberikan tempat bagi setiap anggota keluarga, menghargai perubahan yang terjadi dan mengajarkan keterampilan berinteraksi sedini mungkin pada anak dengan lingkungan yang lebih luas.

5. Kualitas dan kuantitas konflik yang minim

Faktor lain yang tidak kalah pentingnya dalam menciptakan keharmonisan keluarga adalah sering terjadi perselisihan dan pertengkaran maka suasana dalam keluarga tidak lagi menyenangkan, dalam keluarga yang harmonis setiap anggota keluarga berusaha menyelesaikan masalah dengan kepala dingin dan mencari menyelesaikan terbaik dari setiap permasalahan

\section{Adanya hubungan atau ikatan yang erat antara anggota keluarga}

Keluarga yang memunyai hubungan yang erat juga menentukan harmonis atau tidaknya sebuah keluarga, apabila dalam suatu keluarga tidak memiliki hubungan erat maka antara anggota keluarga tidak adalagi rasa saling memiliki dan rasa kebersamaan akan kurang, hubungan yang erat antara anggota keluarga ini dapat diwujudkan dengan adanya kebersamaan, komunikasi yang baik antara anggota keluarga dan saling menghargai.

Keenam kriteria tersebut mempunyai hubungan yang erat satu dengan yang lainnya, proses tumbuh kembangnya anak sangat ditentukan dari berfungsi atau tidaknya keenam kriteria di atas untuk menciptakan keluarga yang harmonis peran dan fungsi orangtua sangat menentukan keluarga yang tidak bahagia atau tidak harmonis akan mengakibatkan persentase anak menjadi nakal semakin tinggi.

\section{STRES KERJA DENGAN KEHARMONISAN KELUARGA}

Stres sebagai suatu keadaan yang dapat memengaruhi kondisi fisik dan mental seseorang pada saat dia dihadapkan pada sebuah kesempatan, keterbatasan atau tuntutan yang dihubungkan dengan apa yang diinginkan yang hasilnya kemudian dipersepsikan sebagai sesuatu yang tidak pasti. Stres tidak selalu memilki dampak negatif, stres juga memilki dampak positif, terutama bila stres tersebut ndapat memberikan suatu input yang memilki potensi, seperti pada motivasi pribadi, rangsangan untuk bekerja lebih keras, dan meningkatnya inspirasi hidup yang lebih baik.

Stres yang memiliki dampak positif seperti adanya motifasi pribadi merupakan sebuah indikasi seseorang mampu menciptakan keharmonisan dalam keluarganya. Hal ini sejalan dengan pendapat dengan Mitrofan dan Ciuperca (Adriana, 2012) menjelaskan bahwa keharmonisan keluarga adalah bagaimana suami dan istri dapat melakukan komunikasi, motifasi, serta mengetahui lebih dalam tentang pasangannya dalam mengembangkan hubungannya sebagai suatu keluarga.

\section{PENUTUP}

Uraian di atas menjelaskan bahwa adanya hubungan stres kerja dengan keharmonisan keluarga, seperti produktivitas kerja, dapat menjadi pemicu tidak harmonisnya keluarga mengakibatkan pertengkaran antara suami dan istri yang berujung pada perceraian, kurangnya perhatian serta komunikasi yang erat dengan anak dan keluarga. Bagi wanita pekerja dan juga berperan sebagai ibu rumah tangga 
Subhan Ajrin Sudirman, Stress Kerja dengan Keharmonisan Keluarga.... 85

mempunyai beban lebih berat dari rekan prianya, yakni mengatasi urusan keluarga yang menyangkut rumah tangga serta menyelesaikan urusan kerja baik di kantor ataupun di lapangan yang dijalani terusmenerus dapat mempengaruhi keharmonisan keluarga serta pemicu stres.

\section{DAFTAR KEPUSTAKAAN}

Anoraga, Panji. (2014). Psikologi Kerja, Jakarta : PT Rineka Cipta.

Basri, H. (1996). Keluarga Sakinah Tinjauan Psikologi Dan Agama. Yogakarta: Pustaka Pelajar.

Chaplin, James P.(2005). Kamus Lengkap Psikologi. Jakarta: PT Raja Grafindo Persada (Fajar Interpratama Offset).

Cooper, Cary \& Alison Straw. (2002). Stres manajemen yang sukses dalam sepekan (Sugeng Panut, Penerjemah). Jakarta: Kesaint Blanc.

Dagum , Drs. Save M. (2013). Psikologi Keluarga. Jakarta: PT Rineka Cipta

Darajat, Zakiah. (1984). Islam dan peranan wanita, Jakarta : Bulan Bintang.

Dhania, Dhini Rama. (2010). Pengaruh stres kerja, beban kerja terhadap kepuasan kerja. Jurnal Psikologi; Vol 01 (01).

Gunarsa, D. (2012) .Psikologi Keluarga, Jakarta : PT BPK Gunung Mulia.

Harisman, Okta Wisudawati dan Wijaksono, Andre Dwijanto. (2013). Pengaruh Stres Kerja Terhadap Produktivitas Kerja Melalui Kepuasan Kerja Jurnal Ilmu Manajemen.
Mahmudah, Siti. (2012). Peran wanita dalam menciptakan keluarga sakinah. Jurnal Psikologi.

Mubarok, Achmad . (2016). Psikologi keluarga. Malang: Madani.

Munandar, Ashar Sunyoto. (2001). Psikologi Industri dan Organisasi. Jakarta: UIPress.

Ratnawati, Peni. Keharmonisan Keluarga Antara Suami Istri Ditinjau dari Kematangan Emosi Pada Pernikahan Usia Dini. Jurnal Psikologi Universitas Semarang

Samosir, Zurni Zahara dan Syahfitri Iin. (2006). Faktor penyebab stres kerja pustakawan pada perpustakaan Universitas Sumatera Utara. Jurnal Studi Pustaka dan Informasi.Vol04 (02).

Sari, Ririn Wedya Putri Mayang dan Ahmad Mardalis. (2015). Pengaruh Konflik Peran Ganda Dan Stres Kerja Terhadap Kinerja Polisi Wanita Di Polresta Surakarta. Naskah Publikasi Program Studi Manajemen Fakultas Ekonomi Dan Bisnis Universitas Muhammadiyah Surakarta

Wijono, Sutarto.( 2010). Psikologi Industri dan Organisasi dalam suatu bidang gerak. Jakarta: Kencana.

Tirtawinata, Christofora Megawati. (2013). Mengupayakan Keluarga yang Harmonis. Kemanggisan Jakarta Barat. Vol 04 (02).

Yusnita,Tri Rita. (2010). Pengaruh Pengembangan Karier Terhadap Konflik Pekerjaan Keluarga Dan Ketakutan Akan Kesuksesan Pada Wanita Serta Dampaknya Pada Prestasi Kerja. Jurnal Psikologi... 